\title{
THE POTENTIAL FOR POSTHUMAN INSIGHTS TO EFFECT SOCIALLY JUST PEDAGOGIES
}

\author{
Brenda Leibowitz
}

University of Johannesburg

brendal@uj.ac.za

Kibashini Naidoo

University of Johannesburg

knaidoo@uj.ac.za

\section{ABSTRACT}

In the South African higher education context, which is fraught with inequities and where many feel uncomfortable, the focus on socially just pedagogies and the positioning of teachers in relation to this is not just timeous and relevant, but crucial. In this article we share what we believe a posthumanist view has to offer researchers and educationists. The article revisits data from a scholarship of teaching and learning (SoTL) research project, in which 23 audio-recorded interviews were conducted with academics from a variety of faculties and units for academic development. We discuss two discourses which emerged from our reading of the data: the first concerns lecturers and students having fixed racial identities that influence how learning does or does not take place and the second concerns students learning in a developmental and teleological manner. We discuss ideas culled from the literature on posthumanist ontologies that helped us to respond to these discourses, and which we believe, could be shared with academics and researchers who wish to advance a socially just pedagogy in higher education. We reflect briefly by way of conclusion on what, as researchers, our responses and responsibility towards the data and the complexities of our time could or should be.

Keywords: higher education; socially just pedagogies; posthumanism; scholarship of teaching and learning; South Africa

\section{INTRODUCTION}

In the South African setting there is a general political fractiousness and awareness of social and material inequality. With regard to higher education in particular, this uneasiness has included a strong calling into question of the settled norms and

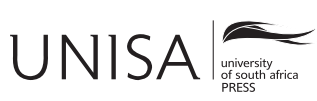

Education as Change

Volume 21 | Number 2 | 2017 | pp. 149-164

www.educationaschange.co.za

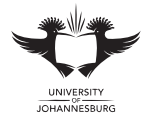

https://doi.org/10.17159/1947-9417/2017/2020 ISSN 1947-9417 (Online), ISSN 1682-3206 (Print)

(C) 2017 The Author(s) 
epistemologies that characterise our universities under the rubric of \#RhodesMustFall, or the "decolonisation of the curriculum" (for example Dennet 2015). At a recent discussion forum on socially engaged academics at the institution in which the authors of this paper work, one of the participants argued that it is difficult to think about a "socially engaged academic," when the "social" in our institutions is so damaged. He said that we teach in a place that is characterised by estrangement and dislocation that speaks to colonialism, apartheid and othering. He maintained that in our society and our higher education institution there is a sense amongst academics of being deeply wounded and damaged. He further stated that as humans we are meant to communicate and teach but in our context we are unable to do so as our abilities to communicate and teach are damaged by the violence of the past and the silences of the present (Mayet 2016).

A problem that constrains us from considering the contestations and troubles of our time from a creative and enabling perspective is the dominant humanist, Cartesian and representationalist ontology within which we tend to frame our teaching and learning practices and our research approach. This ontology influences our reactions to each other - other academics or students, our aims for our classes and for our students, and how we understand our successes and failures. This is a philosophy that sees boundaries between nature and culture and that sees individuals and groups of individuals as fixed or at least as pre-cast; it sees time as linear, moving from the past to the present to the future; it sees teaching as occurring according to pre-set goals (and thus where there are gaps in the repertoires of students who have not yet reached these goals); and finally, it sees researchers as analytic interpreters, external to the situation being researched. This ontology limits how we think about what can be learnt in the teaching and learning situation, by students as well as academics. In an attempt to address the limitations of the humanist ontology adopted previously by us, we shift our gaze to posthumanism.

We contend that posthumanist worldviews pose fresh and transformative lenses with which to consider how academics could position ourselves in order to work towards socially just pedagogies. The value of posthumanism lies in its acknowledgement of the limitations associated with Cartesian dualisms, with the Enlightenment emphasis on difference as negative, with humans as the centre of the universe, with human intentionality and with the distinctions between mind and body, subject and object, nature and culture. The focus of these posthumanist offerings that this paper draws on are identity and difference, and how teaching and learning are viewed. In this article we share our experiences of working through a set of interview transcriptions and how we have been provoked by our engagement with readings on posthumanism and sociomaterialism in order to think differently, or at least, to pose new questions, about relationships in a fractured society and about socially just pedagogies. 


\section{RESEARCH SETTING: THE SOTL@UJ PROJECT}

The study that is reported on in this article is located at the University of Johannesburg, a comprehensive South African university, and within an action-based research project begun at the university in 2014, the SoTL@UJ project. The project sought to provide an interdisciplinary community of practice for academics across faculties and centres for academic development ${ }^{1}$ to support each other in order to foster social justice in and through the curriculum (Kreber 2013; Leibowitz and Bozalek 2016; Moje 2007). (For more information on the project, and discussions on the seminars, see: http:// sotlforsocialjustice.blogspot.com). Participants in the SoTL@UJ project engage in a number of activities which include, amongst others, seminars led by speakers from UJ as well as external to UJ, an annual mini-conference and a blog.

The two authors of this article, together with a third colleague, developed a model to account for the Scholarship of Teaching and Learning (SOTL) as a journey towards a socially just pedagogy. The model was based on the following social justice considerations: participatory parity (using the work of Nancy Fraser 2008, 2009), hope and critique (using the work on critical hope, discussed in Bozalek, Carolissen, Leibowitz and Boler 2014), work on affect (Zembylas 2012, 2010) as well as cognition, and finally, relationality in relation to identity and belonging (Yuval-Davis 2010). We reflected on this model in "Teaching in and for Social Justice" (Leibowitz, Naidoo and Mayet 2017). That model, derived from an initial conceptual framework to guide the SoTL@UJ project, was interrogated in the light of 23 interviews, conducted by project members with other project members as well as with non-project members from a range of disciplines. While analysing the interview transcripts for the publication referred to above, we were struck by clusters of ideas that we were not sure how to respond to, and wanted to explore further. We found posthumanist writings (in particular Barad 2007, 2010; Braidotti 2013; Haraway 2016) to be the most generative, in order to respond to the clusters of ideas - or discourses - that for us emerged from the transcripts. We understand discourses to be cohesive although not entirely homogenous sets of ideas (Crist 2016). The discourses that emerged from the interviews that provoked or moved us are: the idea of identities as being fixed in time, and with difference as an explanation for the troubles affecting learning for social justice; and the notion that teaching is about knowledge transfer where it is primarily the student that learns or the student that moves from being ignorant towards being learned. We intuitively thought that re-reading the data through a posthumanist lens may offer greater insights and help us consider how our responses could be more creative or enabling.

1 By "academic development" we mean support for academics to learn to teach (known alternatively as professional development or faculty development) with the use of technology in teaching and learning, postgraduate studies and for student learning. 


\section{RESEARCH APPROACH}

In a prior publication (Leibowitz, Naidoo and Mayet 2017) we reported on the interviews using a fairly traditional representationalist approach where we as the researchers, outside or above the data, read the data and interpreted it to mirror the "true state" of reality, which at the time we felt we would be in a position to pass judgement upon. The problem with critique and judgement is that it "is so sure of itself" (Massumi 2015, 15). Massumi suggests that judgement can be limiting as it pins down rather than encourages risk, and that it should be complemented by other approaches. The analysis on which the original chapter was based used the excerpts from the transcriptions to determine what the data represents, and in this way to discover what the world is like, with the researcher as the "voice" of the data (Masny 2012, 21). Faithful to this approach, we clustered units of meaning into themes or codes, which has been criticised by sociomaterialists and posthumanists (MacLure 2014; St Pierre and Jackson 2014) for imposing categories and for deadening the data. "Non-representational research," however, seeks originality and creativity, rather than to reveal the "truth" (Vannini 2015). Statements in the interviews set us off on a path of wondering, not unlike a posthumanist approach where one responds to data that "glows" (MacLure 2013). Our initial impulse in response to several statements in the transcripts was to criticise some and praise others, and we wondered whether this was ethical or fair. We were concerned that by taking a representational stance in the original article our intra-action with the data was limiting, preventing us from seeing the vibrancy of the data. The solution to this, it seemed, was twofold: first, to see ourselves as part of the situation rather than external to it, above it, and as judging (Springgay 2015). Thus our re-reading of the data followed a more diffractive approach, which Barad describes as

a method of diffractively reading insights through one another, building new insights and attentively and carefully reading for differences that matter in their fine detail, together with recognition that there intrinsic to this is an ethics that is not predicated on externality, but rather entanglement. (Barad in Dolphijn and van der Tuin 2012, 50)

It is these diffractive readings that enabled us as researchers not just to identify the discourses but to be affected by them, and to use them to think about socially just pedagogies differently. From a social justice point of view, posthumanism is "affirmative" (Braidotti 2013). For this study on scholarship for social justice, affirmative politics implies "the creation of sustainable alternatives geared to the construction of social horizons of hope, while at the same time doing critical theory, which implies resistance to the present" (Braidotti 2011, 267). We see these discourses as provocations, thus as opportunities to consider alternative and illuminating ways of seeing. In re-visiting the data we were open to the possibility that with every engagement with the data something interesting may emerge that shapes us as participants and how we think about social justice in teaching and learning. In this sense revisiting the data represents intra-action where the goal is "making a difference" (Barad 2007). 


\section{THE DISCOURSES THAT EMERGED FROM THE RESEARCH}

We discuss two discourses which emerged from our reading of the data: the first concerns how lecturers believe matters of identity-especially racial-influence teaching and learning; the second is about students learning in a developmental and teleological manner.

\section{Identity and Teaching and Learning}

The discourses dealing with identity and difference are intra-actively produced by a myriad social, political and material conditions over time and in time, and are not inherent in and attributable to individuals. The materiality of the discourses and the coming together of the cultural and the material in the production of discourses is most graphically illustrated with regard to the discourses on identity, difference and race, where significant aspects of the entanglements are the physical (for example skin colour), resources (finances allocated to students within different educational systems), power and politics (apartheid and the persistence of race-related inequality) and culture and perceptions (how people see themselves, as black or white, and how they perceive others to see them).

Within this discourse racial identity tends to be seen (though with exceptions, as discussed below) as fixed, as an outcome of the past that interferes with or colludes with the present. This is mostly seen as negative or problematic. There were several variations in this discourse: a) that there is actually no difference based on race, but people believe there is; $b$ ) difference is negative or a challenge, and sameness is positive or comfortable; c) difference should be acknowledged, embraced and worked with. The excerpt below is an example of the idea that there is no real difference, but that students perceive the lecturer's different racial affiliation from their own to be a problem affecting teaching and learning:

I have to keep in mind that my students see me as somebody from a different race group, "What does she know? Ja she knows everything." And I get that, I absolutely get it, but I can't change that for them. (Respondent 11)

As one of the reviewers of this article wrote, "maybe the academic comes to imagine him or herself as teacher through the ineptitude/ignorance/incompetence of 'the student' here both are being rendered in/capable through the intra-action." The following comment by the same lecturer indicates that she feels perceptions of difference amongst individuals according to race are negative, and that difference does not actually exist:

And my prayer is that one day they (students) will realize that this had nothing to do with race or with gender or with anything, but the colour of our hearts. If that makes sense. It's not the colour of the skin that is important here, for me it's the colour of your heart. (Respondent 11) 
A variant of this discourse is the notion that sameness in the classroom makes aspects of teaching and learning comfortable, thus difference would have provided more obstacles:

Yes, so for me being a darkie like the students, most students were - actually this year I didn't have any non-darkies - so that made it a little bit easier. That dynamic, you know when a white person tells a black child that they're lazy or whatever when a black mama says, "Hey, you get off your backside, you are going to do this and this and that now, or by this time." It's so different, and I find that no matter how much I shout at them in class, they will come to me and say, "You know, this is what's happening with me." (Respondent 18)

That difference is a problem, that it poses challenges or that it renders students incompetent is suggested in the following extract, in which the intra-action of the discursive and the material is foregrounded in this lecturer's anecdote about her relative's son:

I've had a relative, actually a friend in KwaZulu-Natal whose son was first in his family in coming to university. And he said to me, "Where do I sit in class?" So it's something as basic as that. The whole aspect of schools not preparing students. I mean the whole aspect of an academic style of writing, an academic style of talking. The research that students have done have told me that it is English that is required here, not the English from school. They actually get angry with their teachers who taught them in the vernacular because when they come to university, it's a different set of requirements. (Respondent 9)

According to this lecturer the intra-action involves power, material resources such as food and above all, silencing. This requires the lecturer to be attuned and to take responsibility:

And we don't see that because students don't talk about it. And if you don't know your students, they see these power relationships so they will never come to you and say "this is my issue." And then the issue of hunger it's a real problem. ... it requires going the extra mile. It required (me) to be emotionally involved. (Respondent 7)

A counter-discourse about difference is that it may be valuable, and that one wants to find opportunities for both students and lecturers to learn from each other's knowledges:

I think that issues of transformation and social justice have to also be dealt with on the one-onone, that means how do I engage with other knowledges in my classroom, how do I engage with the knowledges of my colleagues that are potentially different to mine, and how do we navigate and create spaces where those conversations can happen? (Respondent 22)

As researchers, what do we do with these extracts that suggest particular ways of seeing identity and the impact of these views on learning for social justice? We found the resources provided by the posthuman perspectives useful in allowing us to interact with the statements critically as well as affirmatively, and to derive useful ideas as resources that we can share with our colleagues in the project, and by extension, with academics interested in socially just pedagogies.

An important view within posthumanism concerns difference: it is both nonessential and central (Braidotti 2013). Difference should be valued and not understood 
as an attribute of the abject other. If it is viewed as valuable, acknowledging difference would enhance relational learning and open up spaces of engagement. Barad (2007) argues for the need to queer identity categories as they do not speak to the complexity of intra-actions. As part of her diffractive approach she experiments with difference to understand how these categories are produced and how they come to matter. One of the questions we need to address is: how do race categories emerge and come to matter in teaching and learning events and how are they reconstituted through intra-action? This is important in socially just pedagogies where the emphasis is on becomingwith (Haraway 2016). From a posthumanist perspective human bodies and physical attributes, like the colour of the skin and heart, are all integral parts of the material world and phenomena like race and sex are materialised through intra-action, which makes them integral to teaching and learning. If one is to teach in a socially just way it is not possible to erase or ignore differences that are present in any teaching and learning encounter. One cannot erase the effects of apartheid, neither can one ignore the inequities in terms of access to resources that are present in teaching and learning encounters. It is important to acknowledge these differences, even if they relate to past events. A socially just pedagogy should consider every encounter as meaningful and as having the potential to transform.

The concern here is that if the focus stays on identity as a fixed notion, the possibilities of becoming with, are ignored. Posthumanists reject the notion of fixed identity. Instead they subscribe to a different view of identity in that identity is not viewed as given, but as fluid, as performed and continuously reworked and reformed. In relation to this Barad writes,

Identity is a phenomenal matter; it is not an individual affair. Identity is multiple within itself; or rather, identity is diffracted through itself-identity is diffraction/différance/differing/deferring/ differentiating. (Barad 2012, 32)

An important aspect of learning through intra-action is an understanding that "individuals" do not pre-exist but materialise within phenomena in their "on-going iteratively intra-active reconfiguring" (Barad 2012, 77). This implies that one does not begin with difference but that differences emerge within phenomena. If one were to consider the teaching and learning context as one such phenomenon, an important part of working in an ethical and socially just way is not to begin with difference as given and constraining, but to examine how differences are produced and why they are important within the phenomenon - from the inside. Barad $(2012,77)$ explains that this is about "the material intra-implications of putting 'oneself' at risk, troubling 'oneself', one's ideas, one's dreams, all the different ways of touching and being in touch, and sensing the differences and entanglements from within."

A significant part of putting relations at risk is to allow oneself to be open to the possibilities of engagement with others - particularly others with whom one is least likely to engage, others who through the intra-action are different and others with 
whom one may not agree. The teaching-learning context in South African higher education offers multiple opportunities for this type of engagement. In posthumanist terms teaching and learning would offer numerous opportunities to conduct what Barad (2012) refers to as diffractive experiments, where one reads insights through one another and explores different patterns of relationality. The same colleague that we referred to in the introduction to this article, who spoke about our social life as damaged, likened the academy to the idea of a sacred space, which it would be a form of blasphemy to vandalise. Thus in academic contexts where part of the sacred ritual is to stay within the boundaries of our disciplines, risk is troublesome. To risk is to actively seek out opportunities that bring together knowledge practices that are different from our own, to see possibility in difference, not only to bring them together but to tear them apart as well. This idea is aligned with Barad's (in Dolphijn and van der Tuin 2012 , 52) diffractive methodology which proposes a cutting together-apart. This is a process where cuts, although violent, "open up and rework the conditions for agential possibilities."

A final point with regard to the discourse of identity is the notion of time where past, present and future are separate and occur in that order, in contrast with a posthuman, queered notion of time, viewed as disjointed (Barad 2010), iterative and non-developmental or teleological (working from the not-developed to the developed) (Barad 2007). One of the extracts we cited expressed the hope that things will be different in the future. This can be read as hope deferred rather than as critical hope (Bozalek et al. 2014). Hope deferred would allow us as educators to delay taking responsibility, or to not take responsibility at all. Haraway suggests that hope involves being present:

Staying with the trouble does not require such a relationship to times called the future. In fact, staying with the trouble requires learning to be truly present, not as a vanishing pivot between awful or edenic pasts and apocalyptic or salvific futures, but as mortal critters entwined as myriad unfinished configurations of place, times, matters, meanings. (Haraway 2016, 1)

Yet this present is a present interwoven with the past, and with the future. It is partly because of the importance of the future that we need to stay with the present. According to Braidotti:

The pursuit of collective projects aimed at the affirmation of hope, rooted in the ordinary micropractices of everyday life, is a strategy to set up, sustain and map out sustainable transformations. The motivation for the social construction of hope is grounded in a sense of responsibility and inter-generational accountability. A fundamental gratuitousness and a sense of hope is part of it. Hope is a way of dreaming up possible futures: an anticipatory virtue that permeates our lives and activates them. It is a powerful motivating force grounded not only in projects that aim at reconstructing the social imaginary, but also in the political economy of desires, affects and creativity that underscore it. (Braidotti 2013, 192)

In the present we can also interact and remake our stories of the past, rework the narratives which we choose to tell about ourselves and our identities and about how these identities 
impact our learning. Considering what time and relationality do in teaching and learning, and in research, allows us to consider the difference between saying: "this narrative, or my understanding and my students' understanding of difference and its impact on learning can change," and saying: "there is no difference, there is no race, there are no feelings about who we are and our pasts." The latter would be more akin to denying the past and its impact on the present, which is not our intention. From the decolonising childhood tradition, there is a particularly interesting example of an approach towards reconfiguring as well as disrupting racialised discourses, which nevertheless features how racialisation is constantly being reconstituted (Pacini-Ketchabaw, Nxumalo and Rowan 2011). In this example the authors use art materials to encourage the children to draw themselves. During the children's drawing and chatting, "bundles of practices [of racialisation] that come together ... do not necessarily stay together" (Pacini-Ketchabaw et al. 2011, 20). Thus there are ways to reconsider how racialised discourses affect our teaching and learning, and where necessary, to disrupt the reconstitution of the racialised subject. We have to find these, rather than to become despondent and alienated.

In the words of Thiele,

A thought based on "difference in itself" is always/already (ethically) concerned or charged. By not taking refuge in any transcendent(al) apriori that governs practices in a prescriptive manner, such thinking and (en)acting (in) this world emphasizes the necessary openness (indeterminacy) and the constitutive undecidability of everything. It matters at every moment how we (en)act (in) this world. (Thiele 2016, 3; emphases in the original)

\section{How Students Learn}

The second discourse emerging from the data is in relation to how students learn. Within this discourse students lack specific skills or knowledges that their lecturers have:

Very specifically my work is focused on giving students access to discursive resources. Kinds of language and knowledge that they may not have. (Respondent 8)

Further, within this discourse, some students "lack" more than others, because of their social positioning:

Students have also got very poor communication skills I found, and because of the cultural differences, they often feel embarrassed to ask somebody ... who's older than them certain questions. (Respondent 19)

Students' lack of knowledge is posed as a constraint that, together with other aspects of the entanglement such as time, renders the lecturer and students incapable:

The biggest challenge is background - what they come into the classroom with ... how varied that is and how helpless I feel. I am constrained by time. My instinct is to sit them all down and 
start from scratch (level the playing fields). I try to introduce more exciting connections-big picture view of maths, how things connect, how it fit together, try to assess that ... but students struggle and they don't like it so I am driven more to a procedural, recipe-based testing. This was the system I inherited. I tried something different but I have reverted back to this. (Respondent 23)

Thus the teaching and learning situation is an entanglement of the discursive and the material, but equally importantly, between the here-and-now and what went before (e.g. the system the lecturer inherited), between the here-and-now and the institutional (e.g. time as a constraint) or socio-political (e.g. students' prior schooling). Responsibility for teaching for social justice is thus part of the here-and-now, but it is also distributed synchronically as well as diachronically.

Within this discourse there is the idea that the student learns from stable, fixed components of knowledge made possible by the lecturer:

I can give them the information, what they do with that is up to them. (Respondent 11)

Refracted through these is a variation on the discourse, in this case the lecturer is different from her students, but learns that she can learn with them:

I was very young, when I first started teaching. And if I think of doing ABET classes, I wasn't even 20 yet. Working with non-literate and semi-literate workers who were double my age and thinking I had the answers and having these men looking at me and thinking "who are you? You know nothing about the world." And me feeling, you know I've finished matric, and I know things. It was a wonderful humbling experience for me to actually look at these people and think "I have got so much to learn from you" ... the reciprocity of learning from them was a powerful learning experience for me. And so I suppose learning that with our students is also quite important. Challenging, but it's important. (Respondent 22)

Learning with students is more than challenging, it can be "discomforting" or troubling, on the way to being illuminating and transformative:

So at a pedagogical level, definitely the importance of working respectfully, being willing to allow yourself to be discomforted, because as academic staff we tend to locate (ourselves in) very comfortable positions. We know it, we are experts, and we know this stuff. You know, "I have published in this area, this is my field" and often a student comes and really turns that upside down and if you are willing to, and you are open, I think that even extends our ways of knowing. (Respondent 22)

A counter-variant of the discourse is the idea that learning does not happen "inside" the individual, but in relation to others:

But I think in (my discipline) a lot of what we do in reflexivity is to reflect about my thoughts, my practices, my things. But the outcome of that is to then to reflect outwards. So it's not a thing that remains with me. How do I relate them outward, relate to others? If you do field work for example, there's a lot to do with, how do I change in behaviour with others? What do I say to others? So it's not just a personal growth thing, it's a collective growth. (Respondent 7) 
How does a diffractive reading of the data through posthumanist lenses provide insights and resources that could help us to make sense of these fragments? If we view entities as intra-acting (Barad 2007), teachers and students would not be seen as bounded, with separate intentionalities and a separate sense of agency. Rather, students and teachers would become with and through the intra-action. The learning would be occurring in this intra-action. In this account it would be less easy to attribute intention and will to learn to the students alone. The responsibility for the learning, too, would be distributed, with all actors in the assemblage (Latour 2005) having a role, and this would include matters of space, time, artefacts such as textbooks or hand-held devices in the learning situation. It would extend outwards, to government and institutional policies and to economic relations, amongst others.

According to Postma (2012) education through a sociomaterialist lens is seen as fluid. This conception of education is contrary to the belief held by many participants who view students as individuals who need to be socialised into a pre-existing world and who view their role as the teacher who should help them assimilate into this world (Postma 2012). For sociomaterialists students and teachers in combination with other human and non-human materials are part of an assemblage involved in the process of becoming together (Postma 2012).

From a posthumanist viewpoint learning is not seen as cognitive only. Rather, learning is experiential, affective. Writing from a post-constructivist perspective, Roth (2014) describes the relational and experiential effectively:

Learners, however, do not directly encounter the foreign/strange, because it withdraws as what emerges becomes part of the familiar. Learning is constituted by the double movement of withdrawing and becoming familiar. Because this foreign affects students before they know what is happening to them, this notion of the living curriculum as event*-in-the-making has affect and emotion inherently built in. Passibility, pathos, affect, and emotion do not have to be introduced as factors external to cognition ... learning is an experiential manifestation of events*-in-the-making, whereby we know what we learned only after the fact. (Roth 2014, 19)

Most importantly, in terms of possibility, if knowledge is not a fixed and stable entity, there is greater chance of giving rise to "new possibilities" (Roth 2014, 18), which could affect lecturers as well as students.

While we do not wish to deny the importance of knowledge, we do want to question the assumption that rationality is the desirable state for students to achieve and that learners necessarily move from a less rational, to a more rational position. The decolonising childhood literature has played an important role in questioning the salience of this view of learning as a trajectory of development and of rationality as the desired endpoint. According to Taylor and Blaise (2014):

we have never simply been on the way to "becoming" fully rational and autonomous individuals. Instead, we are moving as a constituent part of a collective worldly body — stirred and affected by our relations with all manner of more-than-human others, living and inert, in our common worlds. (Taylor and Blaise 2014, 286) 
Posthumanism allows us not to see students as requiring to travel a predestined path from not knowing to knowing, and from being deficient to having skills. Working from a Deleuzian perspective, MacLure (2016) cautions educators against "grammaticality," and against setting students on a specific path towards desired educational and linguistic goals. Such framing of students as being deficient in terms of the knowledge skills and attributes that are required to succeed in university does not affirm students and their knowledge and ways of being. Postma too (2016) warns against pedagogies where the other is treated as deficient in some way. He argues that these "pedagogies may too easily lapse into the certainty of the knowledge of who the other is and what they need" (Postma 2016, 325). One could of course argue that the "fault" lies not with the lecturer who sees the student as lacking, but far more with the society and dominant culture that construct the lecturer and student in this way, and that attribute value to what the lecturer or the academy has, but that the student, in particular students from certain class and social backgrounds, does not have. With this in mind it is not surprising that students in South Africa have been calling for the decolonisation of the curriculum.

In a higher education context where epistemological access is seen as access to mainly established forms of knowledge (Postma 2016), the focus of classroom interaction tends to be on developing students' proficiency in such knowledge, often articulated as predetermined outcomes. The anticipated result of this is students who all strive to become proficient in meeting the predetermined outcomes - a level of sameness. Any differentiation that occurs is between those who meet the requirements and those who do not. Strict adherence to lesson plans and predetermined outcomes tends to place greater emphasis on what students "lack" rather than on the opportunities and abilities that come and that are afforded in teaching and learning events (Postma 2016). A posthumanist perspective would suggest that a teaching and learning event should more appropriately be approached with curiosity. Referring to the work of Despret and the value of cultivating curiosity, Haraway (2016) suggests that approaches that attribute pre-established natures and abilities to particular beings need to be disrupted. For teaching and learning encounters this implies the need to question the notion that both students and academics are separate bodies with their own intentionalities. Rather, each teaching moment, including classroom encounters, are intra-active and not entirely pre-determined in terms of pre-existing abilities and pre-subscribed roles. Intra-action differs from interaction as it does not assume the pre-existence of entities (Postma 2016) and acknowledges the relationality through which different entities are constituted.

To open ourselves up to learning from our students is risky but necessary during these troubled times. The "risk" in this is that it could result in different ways of being in teaching and learning. For example, being open to learning from and with students puts the traditional idea of students learning from the teacher at risk. Haraway (2016) argues that we need to make, settle or stay with "the trouble":

Our task is to make trouble, to stir up potent response to devastating events, as well as to settle troubled waters and rebuild quiet places. In urgent times, many of us are tempted to address 
trouble in terms of making an imagined future safe, of stopping something from happening that looms in the future, of clearing away the present and the past in order to make futures for coming generations. (Haraway 2016, 1)

Stirring up trouble or allowing for discomfort is one injunction that a posthumanist approach might call for, but another injunction, also relating to difference, that is perhaps more difficult to concretise, is to see ourselves within the affirmative flow of relations that for example Braidotti writes about:

The posthuman recomposition of human interaction that I propose is not the same as the reactive bond of vulnerability, but is an affirmative bond that locates the subject in the flow of affirmative relations with multiple others. (Braidotti 2013, 50)

\section{CONCLUDING THOUGHTS}

We have isolated two significant discourses that emerged for us in our re-reading of the 23 transcripts conducted as part of the SOTL@UJ project. These discourses concerned ideas about identity as fixed, often racialised and troublesome, and about learning as teleological, rational and occurring according to a set path set by the teacher or the curriculum. We have diffracted these discourses through posthumanist readings, which we believe suggest useful ways of thinking, feeling about and responding to the discourses. These useful ways, we believe, we could share, as intellectual resources, with the lecturers in our project and with lecturers more broadly.

Haraway $(2016,35)$ shares an important lesson she learnt from Strathern: "it matters what ideas we use to think other ideas." Thus it is useful for us, our project members and educationists more broadly, to diffract the discourses that prevail in higher education, and to consider them both critically as well as affirmatively, in the light of the new insights offered by posthumanism. We should be asking, what ideas should we be using to think other ideas? And what might those ideas be? What discursive and material conditions need to prevail in order for us to think and learn with?

The extracts are from interviews with individuals. We hope we have shown how the extracts suggest intra-actions of phenomena that encompass more than the individual, more than the here and now, and thus that responsibility for effecting socially just pedagogies, too, is distributed - amongst lecturer and students, lecturer and colleagues, the institution that legislates a particular, timebound timetable, the society that continues to allow substandard conditions for general schooling, and so on.

But what of ourselves as researchers, as actors within the moment of reading? How are we shaping and being shaped by the data, which is part of the intra-action and is helping to shape our thinking and feeling and affect (as "intensitives of feeling" [Massumi 2015, x])? We have to remind ourselves not to only critique and judgeperhaps also to feel with the ideas and the interviewees, to feel our own investment in this discourse of student learning as well as to be moved to action. Barad's (2007) 
concept of "ethico-onto-epistemology" reminds us of the inseparability of ontology, epistemology and ethics, and thus of our ethical responsibilities as researchers. We thus leave ourselves, the participants in the SOTL@UJ project and the readers with our concluding thoughts: all teaching is "ethically charged" requiring us to make decisions that matter, constantly. Similarly, all research is ethically charged. There is always the chance to make a difference, since life is indeterminate.

\section{REFERENCES}

Barad, K. 2007. Meeting the Universe Half-Way: Quantum Physics and the Entanglement of Matter and Meaning. Durham: Duke University Press. https://doi.org/10.1215/9780822388128

Barad, K. 2010. "Quantum Entanglements and Hauntological Relations of Inheritance: Dis/Continuities, SpaceTime Enfoldings, and Justice-to-Come." Derrida Today 3 (2): 240-68. https://doi.org/10.3366/ drt.2010.0206

Barad, K. 2012. "Intra-Actions: An Interview with Karan Barad by Adam Kleinman.” Mousse 34: 76-81.

Bozalek, V., R. Carolissen, B. Leibowitz, and M. Boler. 2014. Introduction to Discerning Critical Hope in Educational Practices, edited by V. Bozalek, B. Leibowitz, R. Carolissen and M. Boler. London: Routledge.

Braidotti, R. 2011. Nomadic Theory. The Portable Rosi Braidotti. New York: Columbia University Press.

Braidotti, R. 2013. The Posthuman. Cambridge: Polity Press.

Crist, E. 2016. “On the Poverty of Our Nomenclature.” In Anthropocene or Capitalocene? Nature, History and the Crisis of Capitalism, edited by J.W. Moore. Michigan: PM Press.

Dolphijn, R., and I. van der Tuin. 2012. New Materialism: Interviews and Cartographies. Michigan: Open Humanities Press. https://doi.org/10.3998/ohp.11515701.0001.001

Dennett, B. 2015. "Rhodes University: A Demand for Transformation." Mail\&Guardian, September 9. https://mg.co.za/article/2015-09-09-rhodes-university-a-demand-for-transformation (accessed March 20, 2017).

Fraser, N. 2008. "Reframing Justice in a Globalizing World." In Adding Insult to Injury: Nancy Fraser Debates her Critics, edited by K. Olson, 273-91. London: Verso.

Fraser, N. 2009. Scales of Justice: Reimagining Political Space in a Globalizing World. New York: Columbia University Press.

Haraway, D. 2016. Staying with the Trouble: Making Kin in the Chuthulucene. Durham: Duke University Press. https://doi.org/10.1215/9780822373780

Kreber, C. 2013. Authenticity in and through Teaching in Higher Education. Abingdon: Routledge.

Latour, B. 2005. Reassembling the Social: An Introduction to Actor-Network-Theory. Oxford: Oxford University Press. 
Leibowitz, B. 2016. "Report on the First Seminar at UJ: Decolonising the Curriculum, Teaching and Learning at UJ." http://sotlforsocialjustice.blogspot.co.za/2016/03/first-seminar-at-uj-decolonizing (accessed March 2, 2017).

Leibowitz, B., and V. Bozalek. 2016. "The Scholarship of Teaching and Learning from a Social Justice Perspective." Teaching in Higher Education 21 (2): 109-22. https://doi.org/10.1080/13562517.201 5.1115971

Leibowitz, B., K. Naidoo, and R. Mayet. 2017. "Teaching in and for Social Justice." In Transforming Higher Education: Towards a Socially Just Pedagogy, edited by R. Osman and D. Hornsby, 79-98. Cham: Palgrave. https://doi.org/10.1007/978-3-319-46176-2_5

MacLure, M. 2013. "Researching without Representation? Language and Materiality in Post-Qualitative Methodology." International Journal of Qualitative Studies in Education 26 (6): 658-67. https://doi. org/10.1080/09518398.2013.788755

MacLure, M. 2014. “The Wonder of Data." Cultural Studies-Critical Methodologies 13 (4): 228-32. https://doi.org/10.1177/1532708613487863

MacLure, M. 2016. "The Refrain of the A-Grammatical Child: Finding Another Language in/for Qualitative Research." Cultural Studies-Critical Methodologies 16 (2): 173-82. https://doi. org/10.1177/1532708616639333

Masny, D. 2012. “Cartographies of Multiple Literacies.” In Mapping Multiple Literacies: An Introduction to Deleuzian Literacy Studies, edited by D. Masny and D. Cole, 15-42. London: Continuum.

Massumi, B. 2015. Politics of Affect. Cambridge: Polity.

Mayet, R. 2016. "The Role of the Socially Engaged Academic - Meeting at the University of Johannesburg on 31 October 2016." http://sotlforsocialjustice.blogspot.co.za/2016/11/the-role-of-socially-engagedacademic.html (accessed May 20, 2017).

Moje, E. 2007. "Developing Socially Just Subject-Matter Instruction: A Review of the Literature on Disciplinary Literacy Teaching." Review of Research in Education 31 (1): 1-44.

Pacini-Ketchabaw, V., F. Nxumalo, and C. Rowan. 2011. "Nomadic Research Practices in Early Childhood: Interrupting Racisms and Colonialisms." Reconceptualising Educational Research Methodology 2 (1): 19-33. https://doi.org/10.7577/rerm.174

Postma, D. 2012. "Educational Change, the Agency of the Educator and Heterogeneous Assemblages." Journal of Education 53: 55-74.

Postma, D. 2016. "The Ethics for Becoming in a Pedagogy for Social Justice: A Posthumanist Perspective." South African Journal of Higher Education 30 (3): 310-28. https://doi.org/10.20853/30-3-651

Roth, W. 2014. Curriculum*-in-the-Making: A Post-Constructivist Perspective. New York: Peter Lang. https://doi.org/10.3726/978-1-4539-1326-0

St. Pierre, E., and A. Jackson. 2014. "Qualitative Data Analysis after Coding." Qualitative Inquiry 20 (6): 715-19. https://doi.org/10.1177/1077800414532435 
Springgay, S. 2015. “'Approximate-Rigorous Abstractions': Propositions of Activation for Posthumanist Research in Education." In Posthumanism and Educational Research, edited by N. Snaza and J. Weaver, 76-88. London: Routledge.

Taylor, A., and M. Blaise. 2014. "Queer Worlding Childhood." Discourse: Studies in the Cultural Politics of Education 35 (3): 377-92. https://doi.org/10.1080/01596306.2014.888842

Thiele, K. 2016. "Quantum Physics and/as Philosophy: Immanence, Diffraction and the Ethics of Mattering." Rhizome: Cultural Studies in Emerging Knowledge 30. http://rhizomes.net/issue30/thiele. html (accessed August 12, 2017).

Vannini, P. 2015. Introduction to Non-Representational Methodologies: Re-Envisioning Research, edited by P. Vannini, 1-18. New York: Routledge.

Yuval-Davis, N. 2010. "Theorizing Identity: Beyond the 'Us' and 'Them' Dichotomy." Patterns of Prejudices 44 (3): 261-80. https://doi.org/10.1080/0031322X.2010.489736

Zembylas, M. 2010. "Teachers' Emotional Experiences of Growing Diversity and Multiculturalism in Schools and the Prospects of an Ethic of Discomfort." Teachers and Teaching: Theory and Practice 16 (6): 703-16. https//doi.org/10.1080/13540602.2010.517687

Zembylas, M. 2012. "Pedagogies of Strategic Empathy: Navigating through the Emotional Complexities of Anti-Racism in Higher Education." Teaching in Higher Education 17: 113-25. https://doi.org/10. $1080 / 13562517.2011 .611869$ 